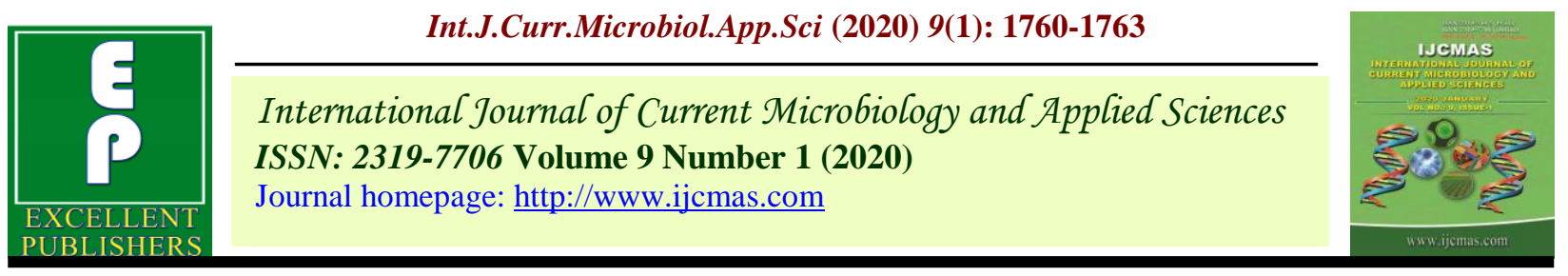

Original Research Article

https://doi.org/10.20546/ijcmas.2020.901.196

\title{
Prevalence of Gastro Intestinal Parasites in Livestock and Poultry in Southern Part of Kanchipuram District, India
}

\author{
M. Murugan and R. Durairajan* \\ Veterinary University Training and Research Centre, Tamil Nadu Veterinary and Animal \\ Sciences University, Melmaruvathur-603 319, Tamil Nadu, India \\ *Corresponding author
}

\section{A B S T R A C T}

\begin{tabular}{|l|}
\hline K e y w o r d s \\
Prevalence, \\
Gastrointestinal \\
parasites, livestock \\
and Poultry \\
\hline Article Info \\
\hline $\begin{array}{l}\text { Accepted: } \\
\text { 15 December } 2019 \\
\text { Available Online: } \\
\text { 20 January 2020 }\end{array}$ \\
\hline
\end{tabular}

\section{Introduction}

Gastro intestinal parasites affects the health of farm animals including poultry by erosion of the digestive tract. It causes interference in the digestion by malabsorbtion thereby decreases milk, egg and meat production. To combat those problems, requisites awareness on the prevalence of gastro intestinal parasite in their geographical location. It is an agricultural region with small scale livestock and poultry farms one of the most important component for substantial income. Hence, this study was taken to know the prevalence of gastro intestinal parasites through fecal examination.

\section{Materials and Methods}

A total of 569 fecal samples were collected from cattle, goat, desi chicken and rabbits in and around Melmaruvathur during mass contact programme and farm visit. The samples were collected in prelabelled container and samples brought to the Veterinary University Training and Research Centre, Melmaruvathur and dispatched to Central University Laboratory, TANUVAS, Chennai 51. The samples were screened for parasitic eggs to know the prevalence of gastro intestinal parasites. The fecal sample was subjected to simple qualitative methods as direct smear examination and 
sedimentation technique. All the samples were screened for presence of parasitic eggs and oocyst and percentage of prevalence recorded.

\section{Results and Discussion}

In the faecal samples screened under simple qualitative techniques, eggs were identified based on the morphological characters of eggs such as Amphistomes sp., Eimeria sp., Strongyle sp., Strongloid sp., Trichuris sp and Toxocara species in dairy cattle. In goat, Eimeria sp., Amphistome sp., Strongyle sp., Strongloid sp., Trichuris sp and cestodal eggs. In poultry, Eimeria sp., Capillaria sp. and Ascarids sp. In Rabbits, Oocyst and Strongloides species of parasitic eggs were identified and tabulated in Table. 1

In this study, more than $50 \%$ of samples were showing negative for helmitic infection which indicates there was no rainfall and scarcity of water logging ponds led to decrease transmission of helmintic infections in the study area.

In cattle, prevalence of eggs of Eimeria sp, Strongyle sp., Strongyle with Eimerai sp., Strongyle with Amphistome sp., Strongloid sp., Trichuris sp and Toxocara were 4.2,5.8 2.6, 0.6, 3.9, 0.6 and 0.6 per cent respectively. Stongyles egg and Eimerai Oocyst is more prevalent than other species. This finding concurs with finding of Muralidharan (2005). They reported that Strongyle was more prevalent than other parasitic eggs. The prevalence of Eimeria in young animals more common than adult animals. The sporulated oocyst may be transferred by licking. In goat, Amphistome sp,Strongyle sp, Eimeria sp, Strongyle sp, Trichuris sp, Strongyle sp and Eimeria Ocyst, Strongloid $\mathrm{sp}$ and eggs of cestodes were $0.5,29.5,5.3,5.1,0.5,2.3,1.1$, 1.1 and 1.1 per cent respectively. Stronglye sp. and Eimeria oocyst were more prevalence in goat. This finding was correlated with finding of Murthy et al., (2014). In goat, high incidence might be due to immunosuppression in the goat that might be due to over population, transportation and herd movement. Trichuris sp. and cestodes eggs were low prevalence in this study indicates that absence of risk factors size of the farm mainly overcrowding and following proper deworming schedule.

In poultry, Eimeria sp , Eimeria oocyst and Capillaria sp, Ascarids and Capillaria, Capillaria and Ascarids sp were 24.6, 1.3, 1.3 4.8, 6.8 per cent respectively. The prevalence of Eimeria in poultry is higher than other parasites is in correlation with report of Sireban et al., (2005). Eimeria oocyst was more prevalent in poultry caused by improper management system and rearing the birds inadequate space can enhance transmission of oocyst and they spreading into healthy birds. Capillaria sp. in poultry causes major problem in this region due to inadequate knowledge on deworming for poultry. This finding was correlated with finding of Rayyan et al., (2010).

In Rabbit also Eimeria is more prevalent than other parasites. In intensive system of rearing, the dung may be transmitted and fast spreading by aerosol, the hair and water spillage in cages. Strongloides sp found very low prevalence in this study.

It is therefore, the periodic awareness programme on deworming through peripheral centre of TANUVAS, 50 per cent of the animal population not identified any helmintic infection. For maximum awareness on deworming by veterinarian to attain healthy farming practices by adopting rotational grazing, periodic deworming and farmers should aware of commonly causing gastro intestinal parasites and other infectious diseases. 
Though all the species viz, cattle, goat, poultry and rabbit showing high prevalence of Coccidiosis and Strongyles infection. The prevalence of value of gastro intestinal parasites was low to moderate in all the species guarantee for treatment. The identified parasites not represent any risk factors to animal and public health.

Table.1 The prevalence of various parasitic eggs and Oocysts of livestock and Poultry

\begin{tabular}{|c|c|c|c|c|c|}
\hline Sl.no & Species & $\begin{array}{c}\text { No. faecal } \\
\text { samples }\end{array}$ & $\begin{array}{l}\text { Gastrointestinal } \\
\text { parasites }\end{array}$ & Positive No. & Percentage \\
\hline \multirow[t]{9}{*}{1.} & \multirow{9}{*}{$\begin{array}{l}\text { Cattle \& } \\
\text { Buffalloe }\end{array}$} & \multirow[t]{9}{*}{308} & Eimeria Oocyst & 13 & 80.8 \\
\hline & & & Strongyle sp. & 18 & 4.2 \\
\hline & & & $\begin{array}{l}\text { Strongyle sp. with } \\
\text { Oocyst }\end{array}$ & 08 & 5.8 \\
\hline & & & $\begin{array}{l}\text { Strongyle sp. } \\
\text { Amphistome sp. }\end{array}$ & 02 & 2.6 \\
\hline & & & Amphistome sp. & 12 & 3.9 \\
\hline & & & Strongloides sp. & 02 & 0.6 \\
\hline & & & Trichuris sp. & 02 & 0.6 \\
\hline & & & Toxocara sp. & 02 & 0.6 \\
\hline & & & No eggs & 249 & 80.8 \\
\hline \multirow[t]{10}{*}{2.} & \multirow[t]{10}{*}{ Sheep and Goat } & \multirow[t]{10}{*}{169} & Amphistome sp. & 01 & 0.5 \\
\hline & & & Strongyle sp. & 50 & 29.5 \\
\hline & & & Eimeria Oocyst & 09 & 5.3 \\
\hline & & & $\begin{array}{l}\text { Strongyle sp. } \\
\text { Trichuris sp. }\end{array}$ & 02 & 1.1 \\
\hline & & & Trichuris sp. & 01 & 0.5 \\
\hline & & & $\begin{array}{l}\text { Strongyle sp. } \\
\text { Eimeria Oocyst }\end{array}$ & 04 & 2.3 \\
\hline & & & $\begin{array}{l}\text { Strongyle sp. } \\
\text { Trichuris sp. } \\
\text { Eimeria Oocyst }\end{array}$ & 02 & 1.1 \\
\hline & & & Strongloides sp. & 02 & 1.1 \\
\hline & & & Cestodes & 02 & 1.1 \\
\hline & & & No eggs & 96 & 56.8 \\
\hline \multirow[t]{6}{*}{3.} & \multirow[t]{6}{*}{ Desi birds } & \multirow[t]{6}{*}{73} & Eimeria Oocyst & 10 & 24.6 \\
\hline & & & $\begin{array}{l}\text { Eimeria Oocyst and } \\
\text { Capillaria sp. }\end{array}$ & 01 & 1.3 \\
\hline & & & $\begin{array}{l}\text { Ascarids sp. and } \\
\text { Capillaria sp. }\end{array}$ & 01 & 1.3 \\
\hline & & & Capillaria sp. & 03 & 4.1 \\
\hline & & & Ascarids sp. & 05 & 6.8 \\
\hline & & & No eggs & 45 & 61.6 \\
\hline \multirow[t]{3}{*}{4} & \multirow[t]{3}{*}{ Rabbit } & \multirow[t]{3}{*}{19} & Eimeria Oocyst & 06 & 31.5 \\
\hline & & & Strongloides sp. & 01 & 6.8 \\
\hline & & & No Eggs & 12 & 63.1 \\
\hline
\end{tabular}


All the livestock owners were aware of the deworming for livestock and poultry. Therfore, to achieve 100 per cent deworming strategy peripheral centre of TANUVAS to create deworming strategy like FMD vaccination programme through extension activities were strengthen by transforming technology from lab to land.

\section{References}

Rayyan, A., Hindi, A, A and Zain, B, A (2010) Occurrence of gastrointestinal helminthes in commercial and free- range chickens in Gaza strip. Palest Egypt Poult. Sci. 30((II)):601-606

Saira Banu, S., Raman, M., Gomathinayagam, $S$ and Dhinakar Raj, G (2009) Preponderance of Eimeria species in commercial poultry in Tamil Nadu. Indian J. Ani . Sci 79(2):164-166

Murthy,G, S, S and Rao, P. V (2014) Prevalence of gastro intestinal parasites in ruminants and poultry in Telangana region of Andhra Pradesh. J. Parasit. Dis 38(2):190-192.

\section{How to cite this article:}

Murugan, M. and Durairajan, R. 2020. Prevalence of Gastro Intestinal Parasites in Livestock and Poultry in Southern Part of Kanchipuram District, India. Int.J.Curr.Microbiol.App.Sci. 9(01): 1760-1763. doi: https://doi.org/10.20546/ijcmas.2020.901.196 